https://doi.org/10.21301/eap.v13i4.13

Vladimir Krivošejev

Narodni muzej Valjevo vladimir.krivosejev@gmail.com

Velisav Marković Fakultet zdravstvenih, pravnih i poslovnih studija Univerzitet Singidunum, Beograd vmarkovic@singidunum.ac.rs

\title{
Muzejske izložbe i autorsko pravo
}

Apstrakt: Izložbe predstavljaju jedan od osnovnih medija preko kojih muzeji prezentuju rezultate svojih aktivnosti, ali i njihov instrument za ostvarivanje dodanih prihoda. One su delo autora koji su po pravilu zaposleni u muzeju i autorstvo ostvaruju realizujući stalne ili povremene obaveze iz radnog odnosa. Ovakav stav otvara pitanja vezana za zakonsku obavezu i realnu praksu ostvarivanja autorskih prava. U radu su obrađene teme izložbe kao autorskog dela, prava muzeja kao poslodavca i zaposlenih kao autora, analizirani su ključni članovi Zakona o autorskom i srodnim pravima u vezi autorskih dela stvorenih u radnom odnosu, te posebno imovinska prava autora izložbe.

Ključne reči: muzej, izložba, kustos, autorsko delo, autorsko pravo, radni odnos

Uobičajena praksa u Srbiji je da se autorstvo izložbe priznaje s aspekta moralnih autorskih prava, ${ }^{1}$ ali je čest slučaj da se ne poštuju imovinska prava autora vezana za isplatu autorske naknade, a ako je naknada i davana, nije isplaćivana shodno odredbama Zakona o autorskim i srodnim pravima (Službeni glasnik 2009), već u skladu s članom 12. Zakona o platama u državnim organima $i$ javnim službama (Službeni glasnik 2001), koji se odnosi na uvećanje plata do $30 \%$ zaposlenim u onim javnim službama koje ostvare prihode koji nisu javni prihodi. ${ }^{2}$ Tako su u nekim muzejima autori, ali uz njih i drugi zaposleni, i to

${ }^{1}$ Tako i Pravilnik o postupku, načinu vrednovanja i kvantitativnom iskazivanju naučnoistraživačkih rezultata istraživača (Službeni glasnik 2016) prepoznaje izložbe kao naučno autorsko delo, što predstavlja svojevrstan nonsens budući da naučne bodove predviđa samo za oblast tehničkih, tehnoloških i biotehničkih nauka.

${ }^{2}$ Čime je usklađen i član 36. Posebnog kolektivnog ugovora za ustanove kulture čiji je osnivač Republika Srbija, autonomna pokrajina i jedinica lokalne samouprave (Službeni glasnik 2015). 
povremeno, ${ }^{3}$ dobijali materijalnu naknadu shodno pojedinačnim i kolektivnim uspesima u vidu ,stimulacije”, i to od sredstava koja su ostvarena naplatom ulaznica za posetu izložbi kao autorskom delu pojedinaca, a što predstavlja drugi pravni osnov i nije autorska naknada.

Takva praksa je ustanovljena zato što u Srbiji, kod uprave muzeja kao poslodavca, kod organa vlasti kao osnivača, ali i kod samih kustosa kao autora, preovlađuje laičko mišljenje da je delo stvoreno u radnom odnosu, realizovano izvršavanjem radnih obaveza za koje se prima plata i da za njega ne sleduje posebna naknada. Na formiranje takve prakse je dodatno uticala i činjenica da su, u većini muzeja u Srbiji, prihodi koje ostvaruju od ulaznica mali, ne retko i simbolični (Krivošejev 2012, 311 i 394), tako da se nije formirao stav o mogućnosti i potrebi isplate autorske naknade.

U aktuelnom trenutku ova problematika zavređuje dodatnu pažnju i zbog činjenice da je u pregovaračkom procesu s Evropskom Unijom tokom 2017. godine otvoreno poglavlje 7 koje se odnosi na zaštitu prava intelektualne svojine.

\section{Izlaganje kao ključna funkcija muzeja}

Širok spektar raznorodnih stručnih aktivnosti koje se obavljaju u muzejima opsežno su razrađivali teoretičari muzeologije (Stransky 1970; Maroević 1993; Gob i Druge 2009; Van Menš 2015), a najkonciznije je prezentovan u aktuelnoj definiciji muzeja Međunarodnog saveta za muzeje - The International Council of Museums: „Muzej je neprofitna, stalna ustanova u službi društva i njegovog razvoja, otvorena za javnosti koja sakuplja, čuva, istražuje, objavljuje i izlaže materijalna i nematerijalna svedočanstva čovečanstva, u svrhu proučavanja, obrazovanja i uživanja" (ICOM 2007) ${ }^{4}$

Proklamovana neprofitnost ${ }^{5}$ rada muzeja ne negira mogućnost komercijalnih aktivnosti i ostvarenja prihoda, ali ti prihodi ne smeju da se tretiraju kao profit, već kao dopunski materijalni resursi kojima se nadomešćuje nedostatak budžetskih sredstava, te se stoga usmeravaju u dodatni kvantitet i kvalitet realizovanja zadataka zbog kojih muzeji postoje (Krivošejev 2012, 39). Jedan od medija, uz pomoć kojih muzeji realizuju svoju važnu misiju, ostvarajući i zaradu, jesu izložbe.

3 Videti više: Krivošejev 2012, 381.

${ }^{4}$ U Srbiji su konkretni zadaci muzeja određeni članovima 65. i 77. Zakona o kulturnim dobrima (Službeni glasnik 1994).

${ }^{5}$ O neprofitno i društveno korisnoj svrsi videti više: Mat, Flac i Lederer 2002, 53; Đukić 2012, 15: Nikodijević 2006, 152; 37. S druge strane, praksa vezana za pojavu sve većeg broja privatnih muzeja otvara pitanje da li te institucije, ako ostvaruju profit, gube pravo da se nazovu muzejima? To pitanje je u toliko aktuelnije kada se ima u vidu da se pojedini muzeji registruju i kao deonička društva (Mat, Flac i Lederer 2002, 47). 
U navedenoj ICOM-ovoj definiciji (ICOM 2007), završna aktivnosti muzejskog rada je izlaganje. Iako izložbe nisu jedini sadržaji muzeja, one su njegovi najuočljiviji elementi kroz koje publika najčešće upoznaje i prepoznaje muzeje. „Izložba je, više ma šta drugo, sredstvo muzeja, instrument njegovog specifičnog govora" (Gob i Druge 2009, 105).

Muzejske izložbe mogu da se klasifikuju po različitim kriterijumima (Krivošejev 2009, 48-50), od kojih je jedan na osnovu dužine trajanja. U skladu s tim, izložbe mogu biti privremene i trajne. Privremene izložbe traju od nekoliko dana ili nedelja do više meseci. Trajne muzejske izložbe, stalne postavke, predstavljaju srž komunikacije svakog muzeja. Osmišljavaju se i realizuju sa ciljem da u istom prostoru traju više godina. Istraživanje stanja regionalnih muzeja u Srbiji, obavljeno 2008. godine, pokazalo je da je prosečna starost stalnih postavki preko 15 godina (Krivošejev 2012, 397). Ni sada, deset godina kasnije, iako su u međuvremenu neki muzeji svoje stare postavke zamenili novim, ${ }^{6}$ stanje se nije mnogo promenilo, budući da su tada nove postavke sada stare više od jedne decenije. ${ }^{7}$

S druge strane, upravo su muzejske izložbe, naročito stalne postavke, sredstva na osnovu kojih, kroz naplatu ulaznica, većina muzeja stiče dodatne prihode. Pri određivanju cena ulaznica u muzeje nemoguće je primeniti ekonomske parametre, $i$ one se formiraju shodno finansijskim mogućnostima posetilaca, uz praksu uvođenja olakšica koje imaju za cilj da omoguće širokoj publici posetu muzejskim sadržajima (Dragićević-Šešić i Stojković 2003, 227; Nikodijević 2006, 134). Ipak, savremene tendencije vezane za liberalizaciju društva nameću očekivanja osnivača da menadžment budžetski finansiranih institucija nađe način da obezbedi što više dodatnih sredstava (Krivošejev 2012, 88). U skladu s tim, muzeji u Srbiji počinju da više pažnje posvećuju sticanju sopstvenih prihoda, mada je nivo uspeha u tome veoma raznolik, kao i posećenost njihovim izložbama. Pomenuto istraživanje stanja regionalnih muzeja u Srbiji pokazalo je da je različite muzejske postavke 2008. godine obišlo od 200 do više od 30.000 posetilaca, a da se procenat učešća ostvarenih sopstvenih prihoda, u odnosu na celokupne godišnje prihode muzeja, kretao od $0 \%$ do $16 \%$, odnosno od par desetina hiljada do više miliona dinara (Krivošejev 2012, 312 i 399).

U odnosu na tadašnje stanje, danas se uočava dodatni razvoj. Tako je u 2008. godini jednu ili dve tada postojeće stalne postavke Narodnog muzeja Valjevo obišlo oko 23.000 pojedinaca, i to 13.805 centralnu postavku a 18.480 postavku u Muselimovom konaku (Krivošejev i Bjeljac 2016, 924), a muzej je od ulaznica prihodovao 2.662.000 dinara (Narodni muzej 2008). Osam godina kasnije,

${ }^{6}$ Nova postavka muzeja u Užicu je otvorena 2014 (Kutlešić 2014), a muzeja u Leskovcu i Šapcu 2015. (Marinković 2015; RTV Šabac 2015).

${ }^{7}$ Nova postavka muzeja u Valjevu svečano je otvorena 2007. godine. Slično je i sa tada novim postavkama u Loznici, Kraljevu, Novom Pazaru... (Krivošejev 2012, 399). 
2016. godine, oko 40.000 različitih pojedinaca je obišlo jednu, dve ili sve tri sada aktivne stalne postavke, ${ }^{8}$ a muzej je ostvario prihod od 8.498.000 dinara (Narodni muzej 2016). Još izrazitiji rast posete, a shodno njemu verovatno i ostvarnih sopstvenih prihoda, imao je Muzej Nikole Tesle u Beogradu, koji je 2008. godine registrovao 12.372, a 2016. godine 100.783 posetilaca (Muzej Nikole Tesle 2016).

Bez obzira o kom tipu izložbe je reč, za sve muzejske izložbe je zajedničko da se na njima ne prezentuju samo muzejski predmeti već i rezultati istraživanja užih i širih konteksta vezanih za muzejske predmete i način i vreme njihovog nastanka i upotrebe, što kroz diskurse muzejske naracije skupu eksponata daje razumljiv smisao (Gob i Druge 2009, 106). To doprinosi razumevanju izložene tematike i stvaranju jedinstvenog vizuelno - narativnog doživljaja, koji je nastao kroz autorski trud muzejskih stručnjaka. U skladu s tim, Zakon o autorskim i srodnim pravima, u članu 5. stav 1, prepoznaje izložbe kao autorska dela: „Autorskim delom smatra se i zbirka koja, s obzirom na izbor i raspored sastavnih delova, ispunjava uslove iz člana 2. stav 1. ovog zakona: enciklopedija, zbornik, antologija, izabrana dela, muzička zbirka, zbirka fotografija, grafička mapa, izložba i sl.)" (Službeni glasnik 2009).

Po pravilu, mada ne i isključivo, autori izložbe su kustosi zaposleni u konkretnom muzeju.

Kada sumiramo dosadašnje izlaganje možemo da zaključimo da muzejske izložbe predstavljaju jedan od osnovnih načina na koji muzeji prezentuju rezultate svoga rada postižući društvenokorisne efekte, ali i sredstvo za ostvarivanje dodanih prihoda, čime se ostvaruju i ekonomski efekti. Izložbe su delo jednog ili više autora, uglavnom zaposlenih u muzeju, a autorstvo je ostvareno u okviru radnog odnosa, realizacijom stalnih ili povremenih obaveza. Ovakav zaključak otvara pitanja vezana za zakonsku obavezu i realnu praksu ostvarivanja autorskih prava, u skladu s aktuelnim Zakonom o autorskim i srodnim pravima koji uređuje i štiti moralna i imovinska prava autora (Službeni glasnik 2009).

\section{Istorijski pregled zakonodavne prakse u Jugoslaviji i Srbiji}

Prvi zakon o zaštiti intelektualne svojine na našim prostorima donet je 1929. godine kada je u Kraljevini Jugoslaviji usvojen Zakon o zaštiti autorskog prava (Službene novine 1929). Naredne 1930. godine Jugoslavija je pristupila Bernskoj konvenciji za zaštitu književnih i umetničkih dela, ${ }^{9}$ koja je i danas osnovni

${ }^{8}$ Centralnu postavku: 23.500; Muselimov konak: 22.000 i Istorijski spomen kompleks u Brankovini 29.000 posetilaca (Narodni muzej 2016).

9 Doneta 1886.godine a menjana i dopunjavana u više navrata: 1900, 1914, 1928, 1948, 1967. i 1971. godine (Popović 2014). 
izvor i uzor kod izrade i donošenja zakona o autorskim pravima na području Evrope (Popović 2014)..$^{10}$

Posle Drugog svetskog rata donet je Zakon o zaštiti autorskog prava (Službeni list 1946), koji je potom zamenjen Zakonom o autorskom pravu (Službeni list 1957). Taj zakon uvodi novinu o autorskom delu stvorenom u radnom odnosu, po kojoj poslodavac ima isključivo pravo da koristiti delo u svrhu svojih potreba bez traženja posebnog dopuštenja od autora (Spaić 1957, 297), s tim da je dužan da navede ime autora dok poslodavac ima pravo korišćenja autorskog dela deset godina; po isteku tog roka to pravo pripada autoru (Velagić i Hocenski 2014). Novi Zakon o autorskom pravu donet je 1968 godine (Službni list 1968). Članom 21 on nalaže da kod autorskih dela stvorenih u radnom odnosu ,radna ili druga organizacija /.../ ima isključivo pravo da /.../ iskorištava autorsko delo koje je u izvršenju svoje radne obaveze stvorio radnik te organizacije /.../ bez traženja dozvole od radnika". Naredni Zakon o autorskom pravu je donet 1978 (Službni list SFRJ 1978; Spajić 1983). Posle raspada SFRJ i formiranja SRJ donet je Zakon o autorskom i srodnim pravima (Službeni list 1998), a sa formiranjem Državne zajednice Srbije i Crne Gore, usvojen je novi zakon s istim imenom (Službeni list 2004). U tom zakonu se prvi put, u članu 6, koji reguliše zbirke kao autorsko delo, eksplicitno navodi i izložba. Do tada je izložba implicitno svrstavana u zbirke kao vrstu autorskog dela. I danas u Srbiji aktuelni Zakon o autorskom i srodnim pravima (Službeni glasnik 2009) u članu 5 eksplicitno navodi i izložbu kao autorsko delo iz kategorije zbirki.

Zbirka je vrsta autorskog dela koja se sastoji od skupa već postojećih autorskih dela i njihovih fragmenata ili drugih podataka. Da bi se izložba smatrala autorskim delom, neophodno je da ispunjava opšte uslove koji se postavljaju za sva autorska dela, a posebno uslov originalnosti. U tom smislu, izložba je autorsko delo ukoliko je njen tvorac ispoljio svoje individualne stvaralačke osobenosti prilikom izbora, rasporeda i organizacije građe od koje se izložba sastoji ${ }^{11}$ (Marković i Popović 2017, 45). ${ }^{12}$

${ }^{10}$ U izdanju izdavačke kuće Gece Kona u Beogradu 1935. godine izlazi kapitalno delo dr Janka Šumana: Komentar zakona o zaštiti autorskog prava i međunarodnih propisa (Šuman 1935).

11 Sudska praksa: „Izložba slika kao zbirka autorskih dela se može smatrati posebnim autorskim delom, ako, s obzirom na izbor i raspored sastavnih delova, predstavlja orginalnu duhovnu tvorevinu", iz rešenja Višeg trgovinskog suda, Pž. 10135/2006 od 06.07.2007. godine.

12 Autorskim delom smatraju se ne samo zbirke autorskih dela, poput književnih i umetničkih tvorevina, već i zbirke građe koja sama po sebi ne predstavlja zaštićeno autorsko delo, poput sudskih odluka, zakona sa tumačenjima i sl, ako te zbirke predstavljaju originalnu duhovnu tvorevinu s obzirom na izbor i raspored prikupljenog i sistematizovanog materijala. Tako mogu biti autorska dela i određeni obrasci, koji su 
Važeći Zakon o autorskom i srodnim pravima (Službeni glasnik 2009) članom 37 propisao je da vlasnik originalnog primerka dela slikarstva, skulpture i fotografije ima pravo da taj primerak izlaže, bez obzira na to da li je delo objavljeno, osim ako je autor, prilikom otuđenja tog originalnog primerka, to izričito i u pisanoj formi zabranio, s tim što autor ne može zabraniti izlaganje originalnog primerka dela koje pripada muzeju, galeriji ili drugoj sličnoj javnoj instituciji. Istim Zakonom, članovima 98-101, propisana su pravila o autorskom delu stvorenom u radnom odnosu.

\section{Prava poslodavca i autora na autorskim delima stvorenim izvršenjem ugovora o radu}

Osnovno pitanje koje se postavlja jeste: kome pripadaju autorska prava na autorskim delima stvorenim izvršenjem ugovora o radu - poslodavcu po čijem nalogu i čijim sredstvima je autorsko delo stvoreno ili zaposlenom, autoru, kao duhovnom tvorcu dela? I pravila po tom pitanju nisu u potpunosti usaglašena na evropskom, a ni na međunarodnom nivou.

Uporednopravno posmatrano u zakonodavstvu i pravnoj teoriji sreću se dva pristupa uređenja autorskog prava: monistički i dualistički. U Nemačkoj je prihvaćeno monističko načelo, prema kome je autorsko pravo jedinstveno subjektivno pravo kojim se štite lični i imovinski interesi autora. Treća lica mogu iskorišćavati autorsko delo u obimu koji je dopustio autor, izvodeći pravo iskorišćavanja iz svog imovinskog autorskog prava. Time se Nemačko pravo ${ }^{13}$ bazira na načelu pripadanja autorskog prava fizičkom licu koje je delo stvorilo, tj. autoru a poslodavac može steći pravo iskorišćavanja od zaposlenog koji ostaje izvorni vlasnik isključivih imovinskih prava (Matanovac-Vučković 2011, 4). S druge strane, u Francuskoj je autorsko pravo uređeno po dualističkom načelu, prema kome su autorska moralna i imovinska prava različite i samostalne, iako međusobno povezane komponente jednog subjektivnog prava. Moralna autorska prava nisu prenosiva za životnim pravnim poslovima, dok imovinska autorska prava jesu. Zakonik o intelektualnom vlasništvu Francuske ${ }^{14}$ uređuje ustupanje pojedinih imovinskih prava autora, pri čemu se primenjuje načelo specifikacije ili određenosti zbog čega se ugovorom o ustupanju mora navesti svako od pojedinačnih imovinskih autorskih prava te odrediti obim i svrha takvog postupanja, kao i njegov teritorijalni i vremenski učinak. Autorsko delo

upotrebljavani na osnovu zakona i drugih propisa i opštih akata kao i katalozi, adresar i slično, što je sve faktičko pitanje (Milić 2009, 189).

${ }_{13}$ Gesetz über Urheberrecht und verwandte Schutzrechte (UrhG)

${ }^{14}$ Code de la propriété itellectuelle (Legifrance). 
stvoreno u radnom odnosu pripada autoru tj. zaposlenom. Da bi poslodavac stekao imovinska autorska prava na delima svojih zaposlenih to mora ugovoriti ugovorom o radu ili drugim ugovorom, poštujući načelo specifikacije ili određenosti (Matanovac-Vučković 2011, 9).

$\mathrm{Za}$ razliku od kontinentalnog prava, prema anglosaksonskom pravu poslodavac se smatra izvornim nosiocem prava, pod uslovom da to pitanje nije drugačije uređeno ugovorom između poslodavca i zaposlenog (Gliha 2006, 812; Marković i Popović 2017, 49-50).

U pravu Srbije koje prihvata, ali ne u potpunosti, monističko načelo, eksplicitno je određeno da je autor fizičko lice koje je stvorilo autorsko delo i on je i nosilac autorskog prava, ${ }^{15}$ ali članom 98 Zakona (Službeni glasnik 2009) propisano je i da, ako je autor stvorio delo tokom trajanja radnog odnosa izvršavajući svoje radne obaveze, poslodavac je ovlašćen da to delo objavi i nosilac je isključivih imovinskih prava na njegovo iskorišćavanje u okviru svoje privredne delatnosti u roku od pet godina od završetka dela, ako opštim aktom ili ugovorom o radu nije drukčije određeno. Ovo rešenje se ne drži u potpunosti principa koja prihvataju kontinentalna prava kao ni principa koje prihvata anglosaksonsko pravo.

Principi Zakona o autorskom i srodnim pravima Srbije (Službeni glasnik 2009) su u suprotnosti sa nekim principima Zakona o radu (Službeni glasnik 2005). Ako bi se pošlo od osnovnog načela autorskog prava, prema kome su autorska dela duhovne tvorevine, koje mogu stvoriti samo fizička lica, nosilac autorskih prava trebalo bi da bude autor, tj. zaposleni koji je delo stvorio. Ako se pođe od principa radnog prava, autorska dela kao i ostali produkti stvoreni izvršenjem ugovora o radu trebalo bi da pripadnu poslodavcu. Rešenje navedenog problema je u određenom pomenutom kompromisu prema kome ličnopravna ovlašćenja, moralna prava, uz pravo na odgovarajuću pravičnu naknadu za iskorišćavanje autorskih dela, pripadaju autoru, a ovlašćenja na ekonomsko iskorišćavanje autorskih dela pripadaju poslodavcu, ali uz ograničenje od pet godina (Miladinović 2013, 102). Posle isteka toga roka dolazi do konverzije prava i isključiva imovinska prava na delu stiče zaposleni autor čime postaje izvorni nosilac autorskog prava, ako nije drukčije uređeno opštim aktom ili ugovorom o radu. To znači da se opštim aktom ili ugovorom o radu može predvideti da poslodavac ima isključiva imovinska prava na delu i nakon pet godina, odnosno u dužem periodu, ali takođe i u kraćem periodu. Ovaj princip je karakterističan

15 Sudska praksa: „Samo fizičko lice koje stvorilo autorsko delo može biti subjekt autorskog prava (moralnog i imovinskog u smislu čl. 8 i čl. 9 st. 1 Zakona o autorskim i srodnim pravima, a ne i društveno politička zajednica odnosno pravno lice na koje se u smislu čl. 19 navedenog Zakona, može preneti samo pravo ekonomskog iskorišćavanja autorskog dela”. Iz presude Višeg suda u Čačku, P. 36/10 od 13.09.2010. godine i presude Apelacionog suda u Kragujevcu, Gž.3845/10 od 31.01.2011. godine. 
za kontinentalno pravo koje počiva na načelu droit d'auteur koje stavlja težište na zaštitu interesa autora. ${ }^{16}$

\section{Analiza ključnih članova Zakona o autorskom i srodnim pravima}

Autorsko pravo je sastavljeno od ličnopravnih i imovinskopravnih ovlašćenja. Ličnopravna ovlašćenja, koja se još nazivaju i moralna prava autora, jesu: ovlašćenje na priznanje autorstva; ovlašćenje na naznačenje imena autora; ovlašćenje na objavljivanje dela; ovlašćenje na zaštitu integriteta dela; ovlašćenje na suprotstavljanje nedostojnom korišćenju dela. Ova prava su neprenosiva i vezana su za ličnost autora.

Imovinskopravna ovlašćenja su: ovlašćenje na korišćenje autorskog dela u telesnom obliku (na umnožavanje dela, na stavljanje primeraka dela u promet, na davanje primeraka dela u zakup); ovlašćenje na korišćenje autorskog dela u bestelesnom obliku (na izvođenje dela, na predstavljanje dela, na prenošenje izvođenja ili predstavljanja, na emitovanje dela, na interaktivno činjenje dela dostupnim javnosti). Izvorni subjekt isključivih imovinskopravnih ovlašćenja je autor (Marković i Popović 2017, 55-76). U skladu sa članom 19 pomenutog Zakona (Službeni glasnik 2009) osnovno imovinsko pravo autora je da ima pravo na ekonomsko iskorišćavanje svog dela i da mu za svako iskorišćavanje od strane drugog lica pripada naknada.

16 Sa druge strane hrvatski Zakon o autorskom pravu i srodnim pravima (Narodne novine 2003) članom 76 ne konkretizuje vremensko ograničenje, već nalaže da od trenutka stvaranja sva autorska prava pripadaju zaposlenom - autoru bez ograničenja, osim ako zaposleni ugovorom o radu ili drugim ugovorom prenese na poslodavca pravo iskorišćavanja njegovog autorskog dela. U Slovenačkom Zakonu o autroskom i srodnim pravima (Uradni list 2007) u članu 101 propisano je da ako je autorsko delo stvorio zaposleni $\mathrm{u}$ ispunjavanju svojih obaveza ili po uputstvu poslodavca, autorsko pravo i druga prava se prenose isključivo na poslodavca deset godina od završetka radova, ukoliko u ugovoru nije drukčije određeno. To je, kako je ranije navedeno, u skladu sa starim zakonodavstvom Jugoslavije. S sruge strane Zakon o autorskom i srodnim pravima $\mathrm{BiH}$ (Službeni glasnik 2010) u članu 100 propisuje je da ,ako autorsko djelo stvori zaposlenik u izvršavanju svojih radnih obaveza ili prema uputstvima poslodavca, smatra se da su sva autorska imovinska prava isključivo prenesena na poslodavca za period od pet godina od dana završetka takvog djela, ako ugovorom ili drugim aktom nije drugačije određeno. Nakon isteka navedenog roka prava poslodavca prestaju tako što se vraćaju autoru, osim ako je poslodavac prije isteka tog roka zatražio njihov ponovni isključivi prijenos bez ograničenja. U tom slučaju autoru pripada pravo na odgovarajuću naknadu za daljnje iskorištavanje njegovog djela". 
Objavljivanjem dela autor prenosi svoje delo iz privatne, tajne, lične sfere u javnu sferu, izlažući svoje duhovne stavove i kreativne sposobnosti opažanju i kritici društvene zajednice (Marković i Popović 2017, 57). Pod pojmom objavljivanja dela treba shvatiti i radnju kojom delo postaje dostupno javnosti. To je oblik saopštavanja javnosti određenog dela zavisno od vrste autorskog dela. Javnost čini veći broj lica koja nisu međusobno povezana rodbinski ili drugim vezama (Marković i Miladinović 2014, 42). Što se tiče ličnopravnih ovlašćenja zaposlenog kao autora, prilikom korišćenja dela stvorenog u radnom odnosu poslodavac je dužan da navede ime, pseudonim ili znak autora. ${ }^{17}$ Ako poslodavac ne označi zaposlenog kao autora koji je delo stvorio, zaposleni ima pravo na naknadu nematerijalne štete, o čemu je sudska praksa izgradila jasan stav. ${ }^{18}$ Značajno je istaći da ako poslodavac ne objavi, odnosno izda delo stvoreno u radnom odnosu u roku predviđenom u opštem aktu, odnosno u ugovoru, pravo na objavljivanje, odnosno izdavanje takvog dela stiče autor. ${ }^{19}$ I pre isteka predviđenog roka od pet godina, poslodavac može dozvoliti autoru da objavi delo (Milić 2011, 256), a u skladu sa članom 100 Zakona (Službeni glasnik 2009), prilikom izdavanja sabranih dela autor ima pravo da i pre isteka navedenog roka, i bez dozvole poslodavca, objavi svoje delo stvoreno u radnom odnosu.

Kao što je naglašeno, članom 98 Zakona (Službeni glasnik 2009) uređena su autorska prava autora koji je stvorio delo tokom trajanja radnog odnosa izvršavajući svoje radne obaveze. Zaposleni su lica koja imaju ugovor o radu s poslodavcem na određeno ili neodređeno vreme i to s punim ili nepunim radnim vremenom. Međutim, kada je reč o autorskim delima stvorenim u radnom odnosu, pod istima treba razumeti autorska dela koja su nastala bilo kojim oblikom radnog angažovanja $u$ smislu odredbi Zakona o radu, tj. aktivnostima koje se mogu podvesti pod radnopravni odnos (Marković i Miladinović 2014, 176). ${ }^{20}$

17 Član 101. Zakona o autorskim i srodnim pravima (Službeni glasnik 2009). Tako i sudska praksa: „Tuženi BB i BB povredili su autorsko moralno pravo tužilje AA, tako što su na CD-u 'Bez ljubavi' pod rednim brojem 13. objavili pesmu 'Gorka čokolada', a da pri tome nisu označili tužilju kao autora teksta”, iz presude Apelacionog suda u Beogradu, Gž. 4328/12 od 12.12.2012. godine.

18 Sudska praksa: „Tužilac je u izvršavanju radne obaveze kod tuženoga stvorio autorsko delo. Tuženi je delo prepisao i nije označio tužioca kao autora dela i time je izvršio povredu njegovih autorskih prava pa ima pravo na naknadu nematerijalne štete, ali nema pravo na naknadu materijalne štete", iz presude Vrhovnog suda Srbije, Rev. br.733/96 od 12.03.1996. godine.

${ }^{19}$ O razlici između objavljivanja i izdavanja dela vidi više u Marković i Miladinović 2014, 41-44.

20 Zakon o patentima (Službeni glasnik 2011) u članu 57 jasno definiše šta se smatra pronalaskom iz radnog odnosa što Zakon o autorskim i srodnim pravima (Službeni glasnik 2009) ne čini. 
Tumačeći dalje odredbu člana 98 Zakona (Službeni glasnik 2009), uočava se da je potrebno da je zaposleni kao autor stvorio delo izvršavajući svoje radne obaveze ${ }^{21}$ koje su predviđene Pravilnikom o organizaciji i sistematizaciji poslova poslodavca, odnosno ugovorom o radu između poslodavca i zaposlenog. ${ }^{22}$ Međutim, u praksi se dešava da se pojedine obaveze smatraju podrazumevajućim i ne konkretizuju se ni Pravilnikom ni Ugovorom, već se „u pogledu obaveza koje nisu eksplicitno sadržane u ugovoru o radu, primenjuju profesionalni običaji ili običaji - praksa kod poslodavca" (Lubarda 2015, 118). I pri tome se, ne retko, prenebregavaju striktne zakonske odredbe.

Odredba člana 98 Zakona (Službeni glasnik 2009) sadrži i normu da je „poslodavac nosilac isključivih imovinskih prava na njegovo iskorišćavanje u okviru svoje privredne delatnosti". ${ }^{23}$ Privredne delatnosti su delatnosti koje se obavljaju radi sticanja prihoda, a njih ne obavljaju samo privredni subjekti, već i druga pravna lica. Konkretno, muzeji su ustanove čiji je pravni status uređen Zakonom o kulturnim dobrima (Službeni glasnik 1994), kao i Zakonom o javnim službama (Službeni glasnik 1991) i Zakonom o kulturi (Službeni glasnik 2009b), a koji predviđaju sticanje sredstava ,prodajom proizvoda i usluga na tržištu”, odnosno prihodovanje na osnovu ,naknada za usluge, prodajom proizvoda, ustupanjem autorskih i srodnih prava", a što se u praksi najčešće manifestuje naplatom ulaznica za posetu izložbama koje su nečije autorsko delo, a ređe i iznajmljivanjem izložbi drugim srodnim institucijama na privremeno izlaganje. I u teoriji je nesporno da autorsko delo može biti stvoreno za vreme radnog odnosa zaposlenog autora i ne samo u okviru delatnosti privrednog subjekta, već i organizacije koja obavlja vanprivrednu delatnost javnih službi (Milić 2011, 253).

21 Sudska praksa: „Tužilac kao autor dela „komična opera u dva dela, adaptacija, dramaturška obrada i libreto u prozi D.M. po istoimenoj komediji Nikola Makijavelija i tužilja autor dela „stihovi za ... komičnu operu u dva dela, po libretu i adaptaciji D.M., istoimene komedije Nikola Makjevelija", imaju pravo potraživanja na ime naknade imovinske i neimovinske štete zbog povrede moralnih i imovinskih autorskih prava. Prema utvrđenom činjeničnom stanju, tužilac D.M. iz B. je počev od ... godine, kada je zasnovao radni odnos na neodređeno vreme kod tuženog, bio na radnom mestu umetničkog direktora u muzičko-scenskom sektoru... U tom periodu je napisao libreto u prozi, uradio dramaturšku obradu i adaptaciju za komičnu operu ..., prema istoimenoj komediji Nikola Makijavelija, iako njegove radne obaveze, kao umetničkog direktora u muzičko-scenskom sektoru, nisu obuhvatale ni pisanje libreta, niti dramaturšku obradu i adaptaciju za operu". Iz presude Vrhovnog kasacionog suda Srbije Rev 70/2015 od 12.11.2015. godine.

22 A u skladu sa članom 24 stav 2, kao i članom 33 Zakon o radu (Službeni glasnik 2005).

23 Delatnosti su uređene Zakonom o klasifikaciji delatnosti (Službeni glasnik 2009a) i Uredbom o klasifikaciji delatnosti (Službeni glasnik 2010a). Delatnost muzeja se nalazi u oblasti 91: delatnost biblioteka, arhiva, muzeja galerija i zbirki i ostale kulturne delatnosti, a konkretno pod šifrom 91.02: delatnost muzeja galerija i zbirki. 


\section{Imovinsko pravo autora izložbe} nastale izvršenjem ugovora o radu

Valja primetiti da zaposleni kao autor dela stvorenog u izvršenju ugovora o radu, u skladu sa članom 98 navedenoga Zakona, ima pravo na naknadu i za vreme kada poslodavac iskorišćava delo u periodu od pet godina od završetka dela. Zakon ne određuje ni iznos naknade ni kriterijume za njen obračun, već navodi paušalno da naknada zavisi „od efekata iskorišćavanja dela”. ${ }^{24} \mathrm{Uz}$ to Zakon, u članu 99, predviđa da se kriterijumi za određivanje naknade, kao i određivanje pojma „efekata iskorišćavanja dela” propisuju sa dve vrste pravnih akata: opštim aktom poslodavca ili ugovorom o radu.

Opšti akt poslodavca kojim treba da se konkretizuju i kriterijumi za autorsku naknadu je kolektivni ugovor kod poslodavca ${ }^{25}$ a ako on nije donet, onda se, kao njegov privremeni supstitut donosi pravilnik o radu, koji ga zamenjuje dok taj ugovor ne bude zaključen, a kad se zaključi važnost pravilnika prestaje.

Druga vrsta pravnog akta koji se pominje u Zakonu, a koji treba da predvidi kriterijume za iznos autorske nadoknade je ugovor o radu i on vrši normativnu ulogu uz kolektivni ugovor kod poslodavca, odnosno uz pravilnik o radu. ${ }^{26}$

Kolektivni ugovor kod poslodavca (ili pravilnik o radu) i ugovor o radu moraju biti u saglasnosti sa zakonom i s opštim i posebnim kolektivnim ugovorom (Ivošević i Ivošević 2015, 40; Lubarda 2015, 374-378) i ne smeju da utvrđuju manja prava i nepovoljnije uslove rada.

U Srbiji od 2011. godine ne postoji Opšti kolektivni ugovor, ${ }^{27}$ a Poseban kolektivni ugovor koji se primenjuje za muzeje i druge ustanove kulture je Poseban kolektivni ugovor za ustanove kulture čiji je osnivač Republika Srbija, autonomna pokrajina i jedinica lokalne samouprave (Službeni glasnik 2015). ${ }^{28}$

${ }^{24}$ Pitanje ,ekonomskog efekta korišćenja dela” smatramo da treba tumačiti i šire od prihoda od prodatih ulaznica. Tako ,nemački zakonodavac uz prihod navodi i drugu korist od korišćenja dela. Ta korist, pre svega, može biti posredna, kao na primer, u slučaju korišćenja autorskog dela u svrhe ekonomske propagande" (Marković 2007, 376).

${ }_{25}$ Bitno je da se naglasi da postoje tri vrste kolektivnih ugovora: opšti, posebni (kolokvijalnno: granski) i kolektivni ugovor kod poslodavca. Oni su definisani članovima 244, 245 i 247 Zakona o radu (Službeni glasnik 2005).

${ }^{26}$ Ugovor o radu može da vrši svoje funkcije i bez pravilnika o radu. Naime, poslodavac s manje od pet zaposlenih, analogno članu 24 stav 5 Zakona o radu (Službeni glasnik 2005) nema obavezu donošenja pravilnika o radu. U takvoj radnoj sredini, za autonomno uređivanje radnog odnosa dovoljan je samo ugovor o radu (Ivošević i Ivošević 2015, 28).

27 Kolektivni ugovori se zaključuju na period do tri godine. Član 263 stav 1. Zakona o radu (Službeni glasnik 2005), a poslednji Opšti kolektivni ugovor je donet 2008. godine (Službeni glasnik 2008) dejstvo prestalo 2011. godine.

${ }^{28}$ Odlukom Vlade Republike Srbije od decembra 2017. godine važenje ovog kolektivnog ugovora je produženo za jednogodišnji period. 
Međutim, ovim posebnim kolektivnim ugovorom nisu konkretnije uređena pitanja autorskih prava zaposlenih u ustanovama kulture, osim što on članom 31 nalaže: „Svim zaposlenima u ustanovama kulture na koje se odnosi zakon o autorskim i srodnim pravima pripada naknada, u skladu sa zakonom". Time on anulira zakonsku odredbu o isplati naknade u zavisnosti „od efekata”, postavljajući isplatu naknade kao neuslovljen imperativ, ali ne izvršava konkretizaciju Zakona pošto ne propisuje ni najosnovnija načela i minimalna prava $\mathrm{u}$ vezi isplate naknade za imovinsko iskorišćavanje autorskog dela, kojih bi se pridržavali poslodavci prilikom donošenja svog opšteg akta ili ugovora o radu.

Takvo stanje ide u prilog poslodavcima koji imaju interes da se autorska prava ne urede posebno, već da se prepuste opštim pravilima ugovornog prava koji odražavaju potrebe slobodne tržišne utakmice (Marković 2007, 362). To stvara dodatne probleme budući da poslodavci svoju zakonsku obavezu ne primenjuju u praksi, tako da pitanje obračuna autorske naknade u većini slučajeva nije uređeno ni Kolektivnim ugovorom kod poslodavca, odnosno Pravilnikom o radu, kao ni ugovorima o radu. Jedan od razloga za to mogao bi biti vezan i za činjenicu da je autorsko pravo odvojeno od radnog prava, a da se u praksi pomenuta interna akta pripremaju presvashodno na osnovu zakonodavstva radnog prava, kao i tumačenja, uputstava i obrazaca zasnovanim na njemu, a koja ne sadrže stavke koje se odnose na autorsko pravo.

U takvim slučajevima, kada prava autora na naknadu nisu konkretizovana, kao i u slučaju nepostojanja pisanog ugovora, moglo bi se primeniti tumačenje člana 70 Zakona (Službeni glasnik 2009) koji uređuje da „Ako autorska naknada nije ugovorena, a prihod ostvaren korišćenjem autorskog dela premašuje troškove njegovog korišćenja u meri koja omogućuje plaćanje autorske naknade, autor, odnosno njegov naslednik, ima pravo da traži izmenu autorskog ugovora radi ugovaranja naknade", ali i načela i odredbe Zakona o obligacionim odnosima (Službeni list 1978a). ${ }^{29}$

Bitna načela obligacionog prava, koja se primenjuju u ovom slučaju, jesu načelo jednakosti ugovornih strana i načelo autonomije volje ugovornih strana, $\mathrm{s}$ jedne strane, i načelo pravičnosti i načelo ekvivalentnosti uzajamnih davanja s druge strane. Kako autorska naknada zaposlenom zavisi od efekata ekonomskog iskorišćavanja dela na tržištu, u trenutku zaključenja ugovora nije poznata vrednost davanja. „Ove okolnosti ukazuju na aleatornu prirodu autorskog ugovora, te i na nemogućnost pravne zaštite ekvivalentnosti uzajamnih prestacija". ${ }^{30}$ Stoga je najvažniji princip koji se primenjuje princip pravičnosti. Rešenje problema je u nalaženju određene proporcije između autorske naknade i ekonomskog efekta korišćenja autorskog dela. Ona najpravičnije može biti

29 A što je i predviđeno članom 67 Zakona o autorskim i srodnim pravima (Službeni glasnik 2009).

30 O ovim načelima i njihovom sukobu vidi više u Marković 2007, 362-364. 
utvrđena u određenom procentu od cene prodatih ulaznica jer time obe zainteresovane strane podjednako preuzimaju i rizik manjeg efekta u poslovanju, $\mathrm{i}$ benefite koje donosi povećanje efekta iskazano kroz veću posetu i veće prihode, što faktički ne bi bilo moguće u slučaju određivanja fiksnog iznosa. Tako je u zakonodavstvu Francuske propisana obaveza ugovaranja proporcionalne naknade: „Autor može preneti prava na svom delu u celini ili delimično. Prenos podrazumeva proporcionalno učešće autora u prihodu od prodaje ili korišćenja dela" član L131-4 (Legifrance). Međutim, proporcija nije zakonom određena kvantitativno što je ostavljeno volji ugovornih strana.

Pošto opšti akt poslodavca donosi sam poslodavac, on može, kao što je sada najčešći slučaj, da uopšte ne propiše mogućnost isplate autorske nadoknade, ili pak da samostalno, vodeći se samo svojim interesima, a ne pravičnim interesima obeju stranu, odredi nepravičnu visinu naknade zaposlenom, najčešće u fiksnom iznosu. Poslodavac ima veću ekonomsku snagu i društveni uticaj od autora, zbog čega je autor u podređenom položaju. I u ovom slučaju se mogu primeniti principi obligacionog prava i zaposleni kao autor može sudskim putem tražiti isplatu primerene naknade. ${ }^{31}$ Ovde se, tumačenjem, može primeniti već navedeni član 70 Zakona (Službeni glasnik 2009).

Dalje, kao što je već naglašeno, posle pet godina od završetka dela isključiva imovinska prava na delu stiče autor, odnosno zaposleni (ako opštima aktom ili ugovorom o radu nije drukčije određeno), i od tada on postaje izvorni nosilac autorskog prava. Posle isteka roka od pet godina od završetka dela, autoru pripadaju, „vraćaju se,” sva imovinskopravna ovlašćenja, koja je do tada imao poslodavac, tako da je autor ovlašćen da ih vrši u punom obimu (Marković i Miladinović 2014, 177).

U slučaju da poslodavac nastavi s ekonomskim iskorišćavanjem autorskog dela zaposlenog bez sklapanja bilo kakvog ugovora s njim kao autorom koji je po isteku pet godina postao vlasnik isključivih autorskih prava, tada bi povređivao imovinska prava zaposlenog kao autora i mogao bi da odgovara i za materijalnu i nematerijalnu štetu, a autor bi imao pravo na građanskopravnu, kaznenopravnu i upravnopravnu zaštitu. ${ }^{32} \mathrm{~S}$ druge strane, poslodavac bi koristio

31 Sudska praksa: „Autor ima pravo na ekonomsko iskorišćavanje svog dela, kao i dela koje je nastalo preradom njegovog dela i pripada mu naknada za svako iskorišćavanje autorskog dela od strane drugog lica". Iz presude Apelacionog suda u Kragujevcu, Gž. 2246/2010 od 19.01.2011. godine.

32 Sudska praksa: ,Visina naknade utvrđuje se u omjeru s naknadom što bi je autor dobio da je onaj koji je iskorištavao djela zatražio dozvolu autora i platio ugovorenu naknadu za iskorištavanje autorskog djela". Iz presude Visokog trgovačkog suda Hrvatske, Pž. 4123/94 od 13. veljače 1996. godine. „Ako naknada nije određena, utvrdiće je sud prema vrednosti rada, prema normalno potrebnom vremenu za takav posao, kao i prema uobičajenoj naknadi za tu vrstu posla, kako je propisano članovima 622 i 623 Zakona 
resurs koji pravno nije u njegovom vlasništvu, i na osnovu toga korišćenja i prihodovao.

Kada je reč o muzejima u Srbiji, oni u većini slučajeva nastavljaju da, kao što su činili i tokom prvih pet godina po stvaranju izložbe kao autorskog dela, ekonomski iskorišćavaju autorsko delo zaposlenog bez autorske naknade i bez posebnog ugovora, što je pravni osnov za podnošenje tužbe zbog povrede imovinskopravnih ovlašćenja neovlašćenog korišćenja autorskog dela.

Autorski ugovori, koje bi poslodavci morali da potpišu s autorima, kako bi poštovali njihova prava, ali i legalno raspolagali sa izložbom kao resursom, su formalni ugovori i zaključuju se u pisanoj formi. Međutim, i u nedostatku pisane forme za korišćenje autorskog dela po isteku pet godina, kao i u trenutku njegovog nastanka, shodno Zakonu o obligacionim odnosima (Službeni list SFRJ 1978a) ne dolazi automatski do ništavosti ugovora već autor ima pravo na naknadu za korišćenje svog autorskog dela i kad ona nije pravnim poslom određena. Ovo pravo se podrazumeva..$^{33}$

Shodno navedenom, zaposleni kao autor, u skladu sa članom 70 Zakona (Službeni glasnik 2009) ima pravo na primerenu naknadu i kada je ona ugovorena, ali u iznosu nesrazmerno manjem od ostvarene dobiti poslodavca.

Visina primerene naknade je ona koja se u pravnom prometu pošteno mora dati u času zaključenja pravnog posla s obzirom na vrstu i opseg korišćenja autorskim delom, uzimajući pritom u obzir i finansijski uspeh u korišćenju, vrstu i obim autorskog dela, trajanje korišćenja, kao i druge elemente na osnovu kojih se može doneti odluka o primerenoj naknadi. Zaposleni kao autor ima pravo zahtevati izmenu ugovora kojim se uređuje zarada odnosno druga naknada za korišćenje njegovog autorskog dela ako je korišćenje autorskog dela omogućilo poslodavcu sticanje prihoda koji je u očiglednoj nesrazmeri s autorovom zaradom, s ciljem da autoru pripadne pravična naknada za korišćenje njegovim autorskim delom (Gliha 2006, 832). Primerena naknada treba da bude uobičajena i poštena. Međutim, ono što je uobičajeno ne mora biti pošteno. Uobičajeno je da muzeji i srodne institucije ne plaćaju naknadu zaposlenim autorima izložbe. Zato se zahteva da bude ispunjen i uslov poštenja, koji podrazumeva sagledavanje i ocenu legitimnih interesa i jedne i druge ugovorne strane (Marković 2007, 367-368).

o obligacionim odnosima". Iz presude Apelacionog suda u Beogradu Gž 14777/10 od 13.05.2011. godine.

33 Sudska praksa: „U konkretnom slučaju između parničnih stranaka je zaključen usmeni autorski ugovor, koji proizvodi pravno dejstvo, i to kao ugovor o delu, jer je tužilac dokazao sadržaj ugovora i prava i obaveze ugovornih strana koje iz njega proizlaze, pa se imaju primeniti odredbe Zakona o obligacionim odnosima koji se odnose na ugovor o delu iz člana 600 Zakona o obligacionim odnosima" Iz presude Apelacionog suda u Beogradu Gž 14777/10 od 13.05.2011. godine. 
Međutim, treba imati u vidu da „kad je reč o korišćenju autorskih dela koja su nastala u radnom odnosu, naknade određene kolektivnim tarifnim ugovorima zaključenim između sindikata zaposlenih autora i udruženja poslodavaca imaju po zakonu karakter primerenih naknada" (Marković 2007), budući da nisu donete jednostranom odlukom poslodavca, već njegovim pregovorima sa sindikatom kao predstavnikom druge strane. Ali, kako smo već videli, takve tarife nisu konkretizovane u postojećem granskom kolektivnom ugovoru.

Prilikom stvaranja izložbe, kao autorskog dela, zaposleni najčešće koristi svoju duhovnu kreativnost a radi sredstvima poslodavca, koristi predmete koji su vlasništvo poslodavca, odnosno predmete koji imaju status kulturnog dobra, ${ }^{34}$ pa se može postaviti pitanje od kakvog je to uticaja na imovinsko pravo zaposlenog kao autora?

Stav izražen u pravnoj književnosti jeste da pravni status autorskog dela, stvorenog u radnom odnosu, neće promeniti ni to što je zaposleni svoje autorsko delo u celosti izradio koristeći se sredstvima poslodavca (prostorijom, materijalom, uređajima, litraturom i sl.), kao ni činjenica da je izradu autorskog dela u celini ili delom finansirao poslodavac direktno ili indirektno iz budžeta ili drugih javnih izvora (Matanovac-Vučković 2011). ${ }^{35}$ Tako je Zakonom o autrorskom pravu i srodnim pravima Hrvatske (Narodne novine 2003) propisano da je autorsko pravo samostalno i nezavisno od prava vlasništva i drugih stvarnih prava na stvari na kojoj je autorsko delo fiksirano. Prenosom svojine na primerku dela, autor ostaje autor dela i zadržava sva prava iskorišćavanja. Sticalac dela postaje njegov vlasnik, ali autorska prava, kako moralna tako i imovinska, ostaju kod autora. Prodajom dela, prenosom svojine na primerku dela ne dolazi do promene autorskog prava već se radi o prenosu svojine na delu ne i prenosu imovinskih prava (Milić 2010, 555). ${ }^{36}$

Međutim, situacija je, u izvesnoj meri, drugačija ako su predmeti izložbe autorska dela drugih lica. Autorskopravna zaštita izložbe kao zbirke ni na koji

${ }^{34}$ Pojam kulturnih dobara je određen članom 2 Zakona o kulturnim dobrima (Službeni glasnik 1994).

${ }^{35}$ Mada nije retko zastupljena ni praksa da autori izložbi na stvaranju konkretnog autorskog dela rade i van redovnog radnog vremena, u svoje slobodno vreme, kao i da koriste i svoje privatne resurse.

36 Tako, Zakon o kulturnim dobrima Srbije (Službeni glasnik 1994) u članu 31 propisuje da je sopstvenik dužan da obezbedi dostupnost kulturnog dobra javnosti. Međutim, sopstvenik ima pravo na pravičnu naknadu u slučaju zabrane korišćenja ili ograničenja korišćenja kulturnog dobra i na naknadu štete koju trpi usled mere kojom je obezbeđena dostupnost kulturnog dobra javnosti (član 30 istog zakona). Dalje, ovaj zakon propisuje i da je sopstvenik dužan da ustupi kulturno dobro radi izlaganja na izložbama organizovanim na osnovu ugovora o međunarodnoj kulturnoj saradnji, odnosno drugim značajnim povremenim izložbama, ako zakonom nije drukčije određeno (član 35). 
način ne ograničava prava autora dela koja su sastavni deo izložbe - zbirke, pod uslovom da su ona autorska dela podložna zaštiti autorskih prava. ${ }^{37}$ Uključenje jednog tuđeg autorskog dela u zbirku ne umanjuje prava autora uključenog dela. Zato korišćenje zbirke nije moguće bez dozvole nosioca autorskog prava na zbirci i nosioca autorskog prava na delima koja su njen sastavni deo. Autor dela koja su sastavni deo zbirke ima sva ličnopravna i imovinskopravna ovlašćenja u potpunosti (Marković i Popović 2017, 45-46), s tim što je, kako je već naglašeno, Zakon (Službeni glasnik 2009) članom 37 propisao da autor ne može zabraniti izlaganje originalnog primerka dela koje pripada muzeju, galeriji ili drugoj sličnoj javnoj instituciji..$^{38}$

\section{Zaključci sa preporukama}

U aktuelnom trenutku u Srbiji, kada je reč o izložbama koje organizuju muzeji i srodne institucije, a koje autorski realizuju zaposleni u tim institucijama, skoro da nije zastupljena praksa primene Zakona o autorskim i srodnim pravima u vezi poštovanja prava autora na naknadu. Smatra se da je takav rad radna obaveza koja se obavlja za uobičajenu platu. Jedan od razloga za to su skromni prihodi koje većina muzeja ostvaruje od prodaje ulaznica, koji ne ostavljaju prostora za analizu i primenu zakonskih odredbi po ovom pitanju. U takvim okolnostima ni poslodavci, ni inspekcijske kontrole, kao ni sami autori ne poznaju zakonsku regulativu, a u pojedinim slučajevima ne postoji ni volja da se ona primeni. Zato ne postoji izgrađena svest o neotuđivosti autorskog prava kao privatnog prava stvaralaca, bar kada je reč o segmentu imovinskog autorskog prava. U skladu s tim, Zakonom propisane odredbe kojima se definišu kriterijumi za određivanje visine posebne naknade zaposlenom za imovinsko iskorišćavanje autorskih dela nisu unete u interna akta muzeja, kao ni u ugovore o radu, što stvara dodatnu osnovu za nepoštovanje imovinskih autorskih prava autora izložbi. Razlog za to možemo tražiti u činjenici da je autorsko pravo odvojeno od radnog prava, a da se pomenuta interna akta pripremaju na osnovu zakona radnog prava i tumačenja, uputstava i obrazaca zasnovanim na njemu.

${ }^{37}$ Primera radi, pored umetničkih dela, koja neosporno predstavljaju autorska dela štićena autorskim pravom, u sastavu izložbe kao zbirke mogu da se nađu i predmeti zanatske ili industrijske izrade, koja ne predstavljaju subjekt zaštite autorskih prava kao umetnička dela čiji je autor preminuo pre više od 70 godina pre nastanka izložbe, te shodno članu 102 Zakona o autorskim i srodnim pravima (Službeni glasnik 2009) prestaje trajanje imovinskih autorskih prava, ali ne i trajanje moralnih autorskih prava.

38 Autor bi u ovom slučaju imao imovinsko pravo na naknadu za korišćenje njegovog autorskog prava. 
Imajući u vidu navedeno stanje, neophodno je da zaposleni autori koriste kolektivno pregovaranje kao jako sredstvo zaštite, i da preko sindikalnog udruživanja kolektivnim ugovorima urede što povoljniji tretman zaštite autorskih prava u radnom odnosu. S tim u vezi potrebno je u Poseban kolektivni ugovor za ustanove kulture čiji je osnivač Republika Srbija, autonomna pokrajina $i$ jedinica lokalne samouprave (Službeni glasnik 2015) izdejstvovati unošenje odredaba o minimalnim kriterijumima za određivanje visine posebne naknade zaposlenom za imovinsko iskorišćavanje autorskih dela od strane poslodavca, a imajući u vidu efekte iskorišćavanja dela i to posebno za prvih pet godina, a posebno za period nakog isteka tog roka.

Nakon normiranja autorskih prava zaposlenih posebnim kolektivnim ugovorom potrebno je da muzeji i srodne ustanove usklade svoje opšte akte (kolektivne ugovore, a ako ih nemaju onda pravilnike o radu) unošenjem konkretnih odredbi o kriterijumima za određivanje visine naknade. Naravno, ovim opštim aktima mogu da se propišu ista ili veća (nipošto manja) prava zaposlenima od prava koja je utvrdio poseban kolektivni ugovor. Najsvrsishodnije rešenje problema je u nalaženju određene proporcije između autorske naknade i ekonomskog efekta korišćenja autorskog dela, tako da nadoknada može biti utvrđena u određenom procentu od cene prodatih ulaznica, čime obe strane podjednako dele kako rizik slabijeg ekonomskog efekta, tako i benefite povećanja efekta.

Na kraju, i pojedinačnim ugovorima o radu treba urediti navedena pitanja i to: samostalno, ukoliko kod poslodavca ne postoji opšti akt, ili pozivanjem na odgovarajuće odredbe opšteg akta. Neophodno je da navedenim aktima budu uređena sva pitanja koja sadrži autorski ugovor (član 69 i član 98 Zakona o autorskom $i$ srodnim pravima) i to za period prvih pet godina i, eventualno, za period nakon tog roka.

Aktuelna pravna neuređenost odnosa poslodavca i zaposlenog, u stvaranju autorskih dela izvršenjem ugovora o radu, dovešće do prebacivanja bremena tumačenja kriterijuma i ostvarivanja prava na naknadu zaposlenih autora na sudove, što će dovesti do komplikovanih sporova i nepotrebnih troškova. Da bi se oni izbegli svoj doprinos na uređenju konkretnih problema, pored poslodavaca, sindikata i autora, trebalo bi da daju i Ministarstvo kulture, kao nadležno za ustanove koje organizuju izložbe, i Ministarstvo trgovine, turizma i telekomunikacija, kao nadležno za nadzor nad poštovanjem autorskih i srodnih parva, ali i Ministarstvo za rad, boračka i socijalna pitanja, budući da se radi o pravu iz radnog odnosa, kao i Državna revizorska institucija, budući da ako muzeji nisu potpisali ugovore o prenosu autorskih prava sa autora, oni raspolažu imovinom koja im donosi prihod, a koja nije njihovo vlasništvo. 


\section{Literatura}

Dragićević-Šešić, Milena i Branimir Stojković. 2009. Kultura - menadžment, animacija, marketing. Beograd: CLIO.

Đukić, Vesna. 2012. Država i kultura - studije savremene kulturne politike. Beograd: Institut za pozorište, film, radio i televiziju Fakulteta dramskih umetnosti.

Gob, Andre i Druge Neomi. 2009. Muzeologija - istorija, razvoj i savremeni izazovi. Beograd: CLIO.

Gliha, Igor. 2006. Prava na autorskim djelima nastalim u radnom odnosu i po narudžbi. Zbornik Pravnog fakulteta u Zagrebu-poseban broj: 791-837.

ICOM. 2007. „Museum Definition”. Pristupljeno 12. 02. 2018. http://icom.museum/ the-vision/museum-definition.

Ivošević, Zoran i Ivošević Milan. 2015. Komentar Zakona o radu. Beograd: JP Službeni glasnik.

Krivošejev, Vladimir. 2008. „Ka novoj postavci - iskustveni putevi”. U Zbornik radova sa stručnih skupova sekcije istoričara Muzejskog društva Srbije, 39-46. Kraljevo Beograd: Muzejsko društvo Srbije.

- - - 2009. Muzeji, publika, marketing - stalne muzejske postavka i Njegova Visost posetilac. Valjevo: Narodni muzej Valjevo.

- - - 2012. Muzeji, menadžment, turizam - ka savremenom muzeju, od teorije do prakse. Valjevo - Beograd: Narodni muzej Valjevo i NIP Obrazovni informator.

- - - 2013. „Neprofitne ustanove kulture i razvoj turizma”. U Zbornik radova sa V naučnog skupa sa međunarodnim učešćem USPON 2013 - preduzetništvo kao šansa, 27-35. Valjevo: Poslovni fakultet Valjevo - Univerzitet Singidunum.

Krivošejev, Vladimir i Željko Bjeljac. 2016. Stalne muzejske postavke od alternativne učionice do turističke atrakcije - uporedna analiza posete postavkama Narodnog muzeja Valjevo u periodima 1951-1961. i 2001-2011. Etnoantropološki problemi 11 (3): 913-933.

Kutlešić, N. 2014. „Nova postavka u muzeju”. Užička nedelja 8. oktobar. Pristupljeno 24. 01. 2018. http://uzickanedelja.rs/nova-postavka-u-muzeju/.

Legifrance. Code de la propriété itellectuelle. Pristupljeno 07. 02. 2018.

https://www.legifrance.gouv.fr/affichCode.do?cidTexte=LEGITEXT000006069414\&dateTexte $=20080129$

Lubarda, Branko. 2015. Uvod u radno pravo. Beograd: Pravni fakultet Univerziteta u Beogradu.

Marinković, Dragan. 2015. „Nova postavka u leskovačkom muzeju posle 40 godina”. Južne vesti 27. januar. Pristupljeno 24. 01. 2018. https://www.juznevesti.com/Kultura/Nova-postavka-u-leskovackom-Muzeju-posle-40-godina.sr.html.

Marković, Slobodan. 2007. Autorsko ugovorno pravo - kreativnost na tržištu. Zbornik radova Fakulteta dramskih umetnosti 11-12: 359-392.

Marković Slobodan i Miladinović Zoran. 2014. Autorsko pravo i srodna prava. Kragujevac: Pravni fakultet Univerziteta u Kragujevcu.

Marković Slobodan i Popović Dušan. 2017. Pravo intelektualne svojine. Beograd: Pravni fakultet Univerziteta u Beogradu.

Maroević, Ivo. 1993. Uvod u muzeologiju. Zagreb: Filozofski fakultet Sveučilišta u Zagrebu. 
Mat, Gerald, Flac Tomas i Lederer Judita. 2002. Menadžment muzeja: umetnost $i$ ekonomija. Beograd: CLIO.

Matanovac-Vučković, Romana. 2011. Pravni status autorskih djela stvorenih u radnom odnosu na sveučilištu. Zbornik Hrvatskog društva za autorsko pravo 11-12: 1-26.

Miladinović, Zoran, 2013. Autorsko delo nastalo izvršenjem ugovora o radu. Zbornik Pravnog fakulteta u Kragujevcu, XXI vek - vek usluga i uslužnog prava: 99-113.

Milić, Dimitrije. 2009. Ekonomsko iskorišćavanje autorskog dela. Pravni život 3-4: 179-194.

Milić, Dimitrije. 2010. Autorski ugovori. Pravo i privreda 4-6: 548-560.

Milić, Dimitrije. 2011. Komentar Zakona o autorskom i srodnim pravima. Beograd: Građevinska knjiga.

Muzej Nikole Tesle. 2016. Statistika posećenosti. Pristupljeno 24. 01. 2018.

http://tesla-museum.org/web/page.php?p=1\&s=130

Narodni muzej Valjevo. 2008. Izveštaj o radu za 2008. godinu. Pristupljeno 21. 01. 2018. http://museum.org.rs/web/?page_id=717

- --. 2016. Izveštaj o radu za 2016. godinu. Pristupljeno 21. 01. 2018. http://museum. org.rs/web/?page id $=717$

Narodne novine. 2003. „Zakon o autorskom pravu i srodnim pravima”. Narodne novine Repbulike Hrvatske, br. 163/2003, 79/2007, 80/2011, 141/2013, 127/2014, 62/2017.

Nikodijević, Dragan. 2006. Uvod u menadžment kulture. Beograd: Univerzitet Megatrend. Popović, Jovan. 2014. „Zaštita autorskog prava i srodnih prava kroz zakonske propise”. U Zbornik Tehnični in vsebinski problemi klasičnega in elektronskega arhiviranja, Radenci.

RTV Šabac. 2015. „Otvaranje nove stalne postavke”. RTV Šabac 2. oktobar. Pristupljeno 24. 01. 2018. http://www.sabac.tv/vesti/13477.

Salma, Jožef. 1988. Obligaciono pravo. Beograd: Naučna knjiga.

Spaić, Vojislav. 1957. Autorsko pravo, Sarajevo: Veselin Masleša.

Spaić, Vojislav.1983. Teorija autorskog prava i autorsko pravo u SFRJ. Beograd: Jugoslavenska autorska agencija.

Stransky, Zbinek. 1970. Pojam muzeologije. Muzeologija 8. Zagreb.

Šuman, Janko. 1935. Komentar zakona o zaštiti autorskog prava i međunarodnih propisa. Beograd: Geca Kon.

Uradni list. 2007. „Zakon o autorskom i srodnim pravima”. Uradni list Slovenije, br. $16 / 2007$.

UrhG - nichtamtliches Inhaltsverzeichnis. Pristupljeno 31. 01. 2018.

http://www.gesetze-im-internet.de/urhg/index.html.

Van Menš, Piter. 2015. Ka metodologiji muzeologije. Beograd: Muzej nauke i tehnike.

Velagić, Zoran i Hocenski Ines. 2014. Autorstvo u Hrvatskim zakonima o autorskom pravu od 1846. do 2007. Libellarium VII (2): 231-252.

\section{Izvori}

Službeni glasnik. 1991. „Zakon o javnim službama”. Sl.glasnik Republike Srbije,br. 42/1991, 71/1994, 79/2005 - dr. Zakon, 81/2005, 83/2005 i 83/2014 - dr. zakon.

Službeni glasnik. 1994. „Zakon o kulturnim dobrima”. Sl. glasnik Republike Srbije, br. 71/1994, 55/2011 - dr. zakon i 99/2011 - dr. zakon. 
Službeni glasnik. 2001. „Zakona o platama u državnim organima i javnim službama”. Sl. glasnik Republike Srbije, br. 34/2001, 62/2006 - dr. zakon, 63/2006 - ispr. dr. zakona, 116/2008 - dr. zakoni, 92/2011, 99/2011 - dr. zakon, 10/2013, 55/2013, 99/2014 i 21/2016-dr. zakon.

Službeni glasnik. 2006. „Zakona o posebnim ovlašćenjima radi efikasne zaštite prava intelektualne svojine". Službeni glasnik Republike Srbije, br. 46/2006 i 104/2009dr. zakon

Službeni glasnik. 2008. „Opšti kolektivni ugovor”. Sl.glasnik Republike Srbije, br. 50/2008, 104/2008, 8/2009.

Službeni glasnik. 2009. „Zakon o autorskim i srodnim pravima”. Sl. glasnik Republike Srbije, br. 104/2009, 99/2011, 119/2012 i 29/2016 - odluka US.

Službeni glasnik. 2009a. „Zakon o klasifikaciji delatnosti”.Sl. glasnik Republike Srbije, br.104/2009.

Službeni glasnik. 2009b. „Zakon o kulturi”. Sl. glasnik Republike Srbije, br.72/2009.

Službeni glasnik. 2010. „Zakon o autorskom i srodnim pravima”. Sl. glasnik BIH, br. $63 / 2010$.

Službeni glasnik. 2010a. „Uredba o klasifikaciji delatnosti”. Sl. glasnik Republike Srbije, br. 54/2010.

Službeni glasnik. 2011. „Zakon o patentima”.Sl.glasnik Republike Srbije, br. 99/2011 i 113/2017-dr. zakon.

Službeni glasnik. 2015. „Poseban kolektivni ugovor za ustanove kulture čiji je osnivač Republika Srbija, autonomna pokrajina i jedinica lokalne samouprave”. Sl. glasnik Republike Srbije, br.10/15.

Službeni glasnik. 2016. „Pravilnik o postupku, načinu vrednovanja i kvantitativnom iskazivanju naučnoistraživačkih rezultata istraživača”. Sl. glasnik RS”, br. 24/2016 i $21 / 2017$

Službene novine. 1929. „Zakon o zaštiti autorskog prava”. Službene novine Kraljevine Jugoslavije br. 304/29.

Službeni list. 1945. „Zakon o zaštiti autorskog prava”. Službeni list FNRJ br. 45/46.

Službeni list. 1957. „Zakon o autorskom pravu”. Službeni list FNRJ br. 36/57, 11/65.

Službeni list. 1968. „Zakon o autorskom pravu”. Službeni list SFRJ br. 30/68.

Službeni list. 1978. „Zakon o autorskom pravu”. Službeni list SFRJ br. 19/78, 24/86, $21 / 89$.

Službeni list. 1978a. „Zakon o obligacionim odnosima”. Službeni list SFRJ br. 29/78, 39/85, 45/89, 57/89, Službeni list SRJ br. 31/93.

Službeni list. 1998. „Zakon o autorskom i srodnim pravima”. Službeni list SRJ br. 24/98.

Službeni list. 2004. „Zakon o autorskom i srodnim pravima”. Službeni list Srbije i Crne Gore, br. 61/2004. 
Vladimir Krivošejev National museum, Valjevo, Serbia

Velisav Marković University Singidunum, Belgrade, Serbia

\section{Museum exhibitions and copyright}

Exhibitions represent one of the basic media through which museums present the results of their activities, but also their instrument for the realization of added revenues. They are the work of the author, who as a rule is employed in the museum and achieve copyrights by realizing permanent or occasional obligations from employment. Such an attitude raises issues related to the legal obligation and the real practice of exercising copyrights. The paper deals with the theme of the exhibition as an author's work, the rights of the museum as an employer and employees as an author, analyzes the key articles of the Copyright and Related Rights Act regarding author works created in the work relationship, and the special property rights of the author of the exhibition.

Key words: museum, exhibition, curator, author work, copyright, employment

\section{Expositions de musée et droit d'auteur}

Les expositions représentent un des principaux medias par lesquels les musées présentent les résultats de leurs activités, mais elles sont également leur moyen pour s'assurer des revenus complémentaires. Elles sont l'œuvre des auteurs qui en général travaillent dans le musée et jouissent de leur qualité d'auteur en remplissant des obligations permanentes ou temporaires liées à leur contrat de travail. Une telle attitude ouvre des questions quant à l'obligation légale et à la pratique réelle des droits d'auteur. Dans cette étude sont traités les thèmes de l'exposition en tant qu'œuvre d'auteur, des droits du musée en qualité d'employeur et de ses employés en qualité d'auteurs; puis ont été analysés les articles principaux de la Loi sur les droits d'auteur et les droits voisins en rapport avec les œuvres d'auteur créées sous contrat de travail, puis plus particulièrement les droits de propriété des auteurs d'expositions.

Mots clés: musée, exposition, conservateur de musée, œuvre d'auteur, droit d'auteur, contrat de travail

Primljeno / Received: 20.02.2018.

Prihvaćeno / Accepted: 26.05.2018. 